\title{
Severe External Genitalia Lesion by Firearm: A Case Report
}

\author{
Mahamat Ali Mahamat ${ }^{*}$, Sidi Sougui1, Choua Ouchemi1', Olivier Ngaringuem¹, \\ Mohamed Jalloh'2, Lamine Niang2, Serigne M. Gueye² \\ ${ }^{1}$ University of N'Djaména and National General Reference Hospital (HGRN), N'Djaména, Tchad \\ ${ }^{2}$ Grand Yoff General Hospital (HOGGY) of Dakar, Dakar, Senegal \\ Email: ${ }^{*}$ doctaali@yahoo.fr
}

Received 25 August 2015; accepted 18 October 2015; published 21 October 2015

Copyright (C) 2015 by authors and Scientific Research Publishing Inc.

This work is licensed under the Creative Commons Attribution International License (CC BY). http://creativecommons.org/licenses/by/4.0/

(c) (i) Open Access

\begin{abstract}
Gunshot wounds to external genitalia are rare either in war field and civilian setting accounting for $2 \%-4 \%$ of all injuries with often a lesion to the urinary tract. We report a case of external genital injury in a 27 years old man, accidentally injured by his own arm when he pressed the trigger of his gun placed in his pants. He had no past medical or surgical history, he presented to the emergency room (ER) with hemorrhagic scrotal and penile injuries with adjacent urethral tissue damage. He underwent a scrotal flap urethroplasty, and realignment of the corpus cavernosa and the tunica albugina. The patient lost his Foley catheter at post-operative day 3 and subsequently developed a urethral stenosis. Gunshot wounds to external genitalia are rare. A good reconstruction is necessary to avoid an impact on sexual and voiding function.
\end{abstract}

\section{Keywords}

Trauma, External Genitalia, Gunshot

\section{Introduction}

Trauma to the external genitalia by gunshot is uncommon either in war field or in civilian setting accounting for $2 \%-4 \%$ of all injuries and concerns mostly young population. They are potentially severe due to the possibility of urinary and sexual complications [1]. The functional outcomes depend on the time to the management. The potential complications are erectile dysfunction and urethral stricture. Such lesions can also involve the digestive tract prompting a colostomy. We report a case of severe lesion to the external genitalia caused by gunshot followed by a review of the literature.

\footnotetext{
"Corresponding author.
}

How to cite this paper: Mahamat, M.A., Sougui, S., Ouchemi, C., Ngaringuem, O., Jalloh, M., Niang, L. and Gueye, S.M. (2015) Severe External Genitalia Lesion by Firearm: A Case Report. Open Journal of Urology, 5, 188-191. 


\section{Case Report}

Mr. N E, 27 years old, was admitted to the surgical emergency ward one hour after a trauma to the external genitalia. He presented a lesion of the scrotum and penis with bleeding that occurred after he accidentally pressed the trigger of a gun placed in his pants. On the examination, the patient had a good general status was haemodynamically stable with a blood pressure of $120 / 80 \mathrm{~mm} / \mathrm{Hg}$ and heart rate of $80 \mathrm{pulse} / \mathrm{mn}$. Clinical examination found an important bleeding, a lesion of the corporal body with irregular linings, a loss of a segment of penile urethra measuring $8 \mathrm{~cm}$ (Figure 1), a scrotal wound sparing the testis and an abrasion of the ventral aspect of the penis. The bullet ended its track at the right thigh.

Plain film abdominal X-Ray did not show a lesion. Blood cell count showed a normal blood cell count with a hemoglobine level of $12 \mathrm{~g} / \mathrm{dl}$.

He underwent a surgical repair under general anesthesia. A cystostomy was performed, then a debridement of the lesion with excision of necrotic zones and a perfect hemostasis was achieved. We then proceeded to aurethroplasty using a vascularized scotal flap (Figure 2), followed by a corporeal body realinement, a closure of the albuginea of the corporal body (Figure 3).

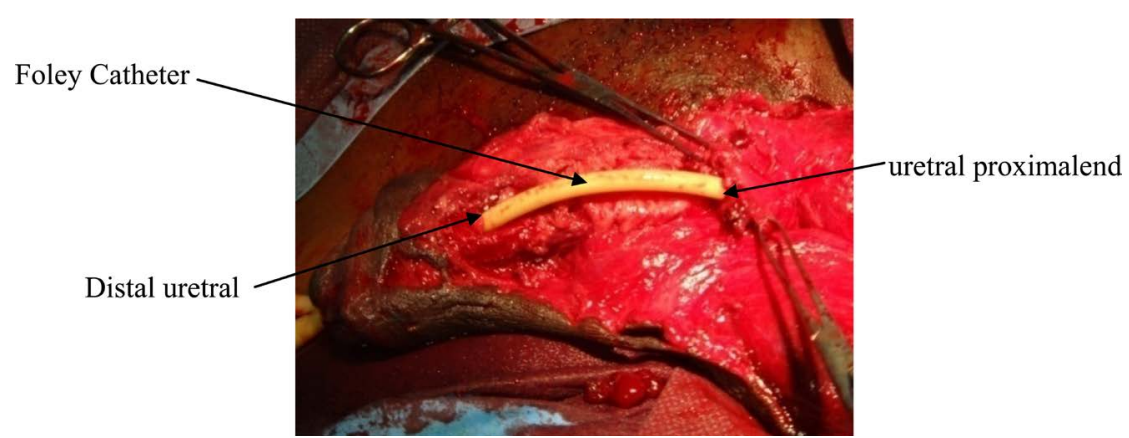

Figure 1. Urethral injury with tissue damage and loss of $8 \mathrm{~cm}$ of the penile urethra.

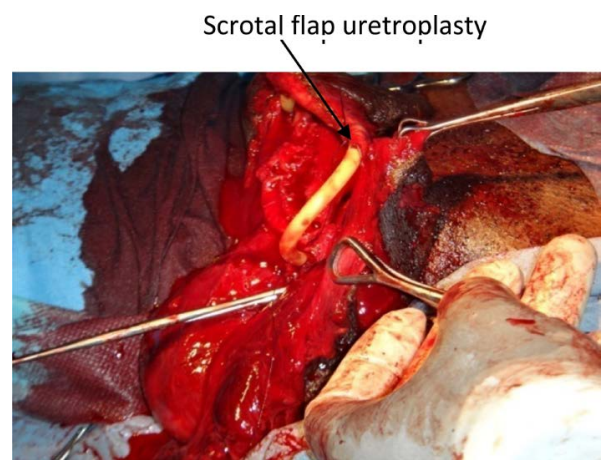

Figure 2. Image showing the technique of scrotal flap urethroplasty used in our patient.

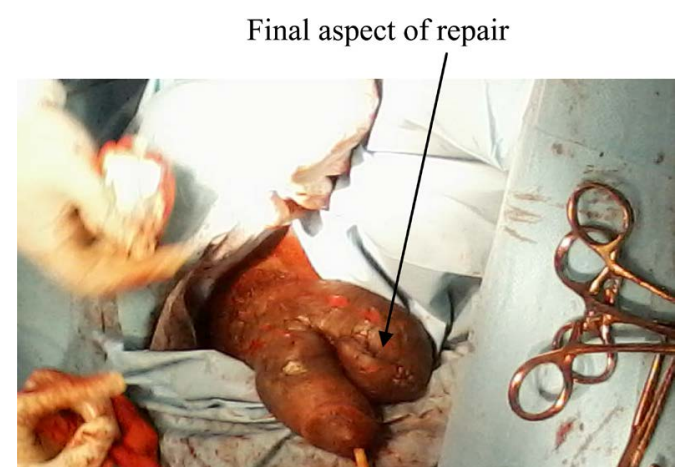

Figure 3. Final view of external genitalia wound repair. 
A course of antibiotics with cefotaxim for 10 days and anti tenanicserotherapy was administered. The Foley catheter fell at post-operative day 3 and he voided by the suprapubic tube. The patient was discharged at pots operative day 14 and was regularly followed up with no other complication. At post-operative day 60, the patient had a good cosmetic outcome with a healing of genital wounds, he reported several spontaneous erections. He still had the suprapubic tube due to inability to void related to the failure of urethroplasty.

\section{Discussion}

External genital gunshot wounds are rare both in war field and in civil practice. They account for $2 \%$ to $4 \%$ of injured patients [2].

In 1991 during war in Croatia, 4425 patients were treated for injuries of which 2.6\% occurred in external genital location [3]. In Senegal, Bah et al. [4] reported six cases in 4 years. Simhan [5] reported 97 cases of scrotal gunshot wound in 20 years in the US. The rarity of the injuries is explained by the anatomy of the perineum, which makes it remote, and narrow, thus limiting the vulnerability to traumatic agents.

Many authors report a profile of the victims as young men with a mean age of 30 years in all series [6] [7] with a predominance of the age group 18 - 28 years [8]. This is explained by the fact that this age group corresponds to the active population that is more exposed because of their activities.

A mean time to admission of 168 minutes was noted by Bah in his series [4]. Our patient was admitted 1 hour after the accident but this shorter time to admission does not reduce the anxiety related to the risk of compromised sexuality and reproduction.

The lesion of the external genitalia is often caused by accidental pressure on the trigger of a gun [4] which was the case of our patient. These gunshot lesions in civilians are caused by accidents related to inability to properly use guns. Open external genital wounds are rarely isolated and often associated with urinary lesions. Urethral lesion is estimated to occur in $21 \%$ - $40 \%$ of cases in civilian conditions [9]. This was the case in our patient who presented external genitalia lesions with loss of a long segment of penile urethra measuring $8 \mathrm{~cm}$ in length.

Management of urethral lesions caused by gunshot wounds is controversial. Due to foreign bodies, bleeding and infection, some authors recommend the placement of cystostomy, a debridement and a staged urethroplasty [10]. Others recommend immediate repair of any penile of bulbar urethral lesion if bleeding is controlled and there is no sepsis [11]. According to HUSMANN DA [9], immediate repair significantly reduces the risk of secondary stenosis ( $12.5 \%$ vs $77 \%$ ) compared to simple realignment by a Foley catheter.

In our case, the urethral lesion was associated with a destruction of the corporal body and albuginea. Such lesion, if not repaired early will lead to fibrosis, pain at erection and erectile dysfunction. Our patient underwent vascularized scrotal flap urethroplasty, a realignment of corporal body and suture of the albuginea. At postoperative day 3, the Foley catheter fell explaining in part the early failure of the urethroplasty. Such a failure can also be explained by the difficulty to assess the vitality of the urethra in this emergency context. That is why in northern America urethroplasty after injury is delayed for 3 months. In the series of Tomislav [3], of 8 patients presenting a wound to the corpora cavernosa, 3 underwent a primary repair with a good functional and cosmetic outcome. In the 5 other cases, the gap in the corporal body was repaired by a transplant using a free flap. Genital gunshot wounds should be repaired primarily with the principle of waterproof suture of the albuginea of corpus cavernosa. Authors report satisfactory outcomes after repair of urogenital gunshot wounds, but there often remain urinary or sexual sequelae that can be irreversible [11].

\section{Conclusion}

Despite the good management and the regular follow up of external genital gunshot wounds, the outcome and prognosis is often limited by the impairment of reproductive urinary or sexual functions.

\section{Conflictof Interest}

None.

\section{References}

[1] Paulhac, P., Desgrandchamps, F., Teillac, P. and Le Duc, A. (1998) Traumatismes récents des organes génitaux 
externes masculins. Encycl Méd Chir (Elsevier, Paris), Techniques chirurgicales-Urologie, 41-417, 9 p.

[2] Salvatierra, O., Rigdon, W.O., Norris, D.M. and Brady, T.W. (1969) Vietnam Experience with 252 Urological War Injuries. The Journal of Urology, 101, 615-620.

[3] Tomislav, L., Antun, T. and Hrvoje, K. (1997) Les blessures de guerre des organes génitaux externes. Progrès en Urologie, 7, 259-261.

[4] Bah, I., Diallo, A.B., Diao, B., Ndoye, A.K., Gueye, S.M., Diallo, M.B., et al. (2006) Les lésions des organes génitaux externes par arme à feu. A propos de six observations à l’hôpital A. Le Dantec, Dakar, Sénégal. African Journal of Urology, 12, 55-59.

[5] Simhan, J., Rothman, J., Canter, D., Reyes, J., Jaffe, W., Pontari, M., et al. (2012) Gunshot Wounds to Scrotum: A Large Single-Institutional 20-Year Experience. BJU International, 109, 1704-1707. http://dx.doi.org/10.1111/j.1464-410X.2011.10631.x

[6] Hodonou, R.K., Diallo, A., Akpo, E.C., Koura, A., Hounassou, P.P. and Goudote, E. (1997) Traumatismes des organes génitaux externes masculin: A propos de 20 cas. Annales d'urologie, 31, 318.

[7] Cerwinka, W.H. and Block, N.L. (2009) Civilian Gunshot Injuries of the Penis: The Miami Experience. Urology, 73, 877-880. http://dx.doi.org/10.1016/j.urology.2008.10.057

[8] Bagga, H.S., Tassian, G.E., Fiser, P.B., Mcculloh, C.E., McAninch, J.W. and Brever, B.N. (2013) Product Related Adult Genitourinary Injuries Treated at Emergency Department in the United States from 2002 to 2010. The Journal of Urology, 189, 1362-1368. http://dx.doi.org/10.1016/j.juro.2012.10.122

[9] Husmann, D.A., Boone, T.B. and Wilson, W.T. (1993) Management of Low Velocity Gunshot Wounds to the Anterior Urthra: The Role of Primary Repair versus Urinary Diversion Only. The Journal of Urology, 150, 70-72.

[10] Pons, F., Rigal, S. and Dupeyron, C. (1997) Les plaies abdomino-pelvi-fessières de guerre, principes du traitement. Annales d'urologie, 31, 294.

[11] Mianné, D., Guillotreau, J., Lonjon, T., Dumurgier, C. and Argeme, M. (1997) Les plaies par arme à feu du bas appareil urinaire chez l'homme Prise en charge chirurgicale dans le contexte de l'urgence. Journal de chirurgie, 134, 139-153. 